\title{
Virilizing Effect of Testosterone and Its Metabolites on the Urovaginal Septum of Female Fetal Rats
}

\author{
Kunio KaWAShima, Shinsuke NAKAURA, Shigeyuki NAGAO, \\ Satoru TANAKA, Tsukasa KUWAMURA and Yoshinito OMORI
}

\author{
Department of Pharmacology, National Institute of \\ Hygienic Sciences, Tokyo 158, Japan
}

\section{Synopsis}

\begin{abstract}
A single injection of $50 \mu \mathrm{g}$ testosterone was given to fetal rats on day $17,18,19$ or 20 of gestation. On day 21 , the fetuses were removed from the mother under maternal ether anesthesia, and the length of the urovaginal septum was measured microscopically in female fetuses in order to assess the virilizing effect of testosterone.

In fetuses treated with testosterone on day 17 , the length of the urovaginal septum was comparable to that of oil-treated littermate controls. In fetuses treated on day 18 , the length was significantly abridged compared with controls. In fetuses treated on day 19 , the abridgment of the urovaginal septum was most marked. In fetuses treated on day 20 , the length of the septum was again comparable to that of controls. The observations suggest that day 19 is the critical day for the virilizing effect of testosterone.

Various amounts of testosterone and its metabolites including dihydrotestosterone, androstane-3 $\beta, 17 \beta$-diol and androstane-3 $\alpha, 17 \beta$-diol were injected into 19-day-old female fetuses, in order to test the dose relation to the virilizing effects of these steroids in terms of abridgment of the urovaginal septum. As a consequence, it was found that testosterone was the most effective for virilization.
\end{abstract}

Testosterone is a predominant androgen formed by the fetal testis during male sexual differentiation (Lipsett and Tullner, 1965; Attal, 1969; Jost, 1970; Wilson and Siiteri, 1973), exerting stimulatory effects on the growth and development of the Wolffian duct and the external male genital organs (Jost, 1970). It has been demonstrated by the experiments that testosterone, when given to the pregnant rat, can be metabolized to dihydrotestosterone, epiandrosterone, androstanediol, androsterone, androstenedione and androstanedione somewhere in the mother and in the placenta (Dell'acqura et al., 1966; Flamigini et al., 1970; Sybulsky, 1970; Rampini et al., 1971; Rembiesa et al., 1971;

Received November 11, 1977.
Milewich and Axelrod, 1972). Such metabolized steroids can cross the placenta to reach the fetus (Schultz and Wilson, 1974). According to the recent information, the androgenic activity of testosterone seems to depend upon dihydrotestosterone which is a principal metabolite of testosterone formed at the site of the target tissues (Wilson and Lasnitzki, 1971; Wilson, 1973). In general, the effects of hormones depend upon a number of variables including absorption from the injection site, transport and binding to proteins in blood, rates of metabolism in maternal tissues and diffusion across the placenta (Schultz and Wilson, 1974).

In the previous report from our laboratory, administration of testosterone to mother 
rats during late pregnancy caused a significant abridgment of the length of the urovaginal septum in female fetuses. The critical day of this effect appeared to be on day 19 of gestation (Kawashima et al., 1977).

The present studies were conducted by giving testosterone directly to the fetuses in utero in order to eliminate the possibility of maternal and/or placental metabolism of the steroid. The studies were, first, to test whether testosterone caused virilization when injected into female fetal rats, and, second, to compare the virilizing activity with that of metabolites of testosterone.

\section{Materials and Methods}

Nulliparous Wistar female rats of more than 13 weeks of age supplied by Nihon Rat Co. Ltd. were mated overnight with males of the same strain. The day of finding sperm in the vaginal smear was counted as the first day of gestation. Thereafter the rats were housed individually.

Androgenic steroids purchased from Sigma Chemical Co. were used in this study. Each steroid was dissolved in olive oil at 5 per cent of concentration and injected directly into fetal rats on the different day from the 17 th to 20 th day of gestation follows.

Pregnant rats were subjected to mid-ventral laparotomy under ether anesthesia and a desired portion of uterine horn with fetuses was exposed out on the abdominal cavity. Each steroid was injected intramuscularly into a fetal rat at its gluteal region through the maternal uterine wall by a $10 \mu l$ syringe (Hamilton Co.) After injection, the uterine horn was returned into the abdominal cavity and abdominal incisions were closed with sutures.

In order to assess the critical period of virilizing effect of testosterone, the injection of $50 \mu \mathrm{g}$ testosterone in $1 \mu l$ of olive oil was made on the $17 \mathrm{th}, 18 \mathrm{th}$, 19 th or 20th day of gestation. The intra-uterine fetuses located in the left maternal uterine horn were treated with testosterone and the fetuses in the contralateral horn received $1 \mu l$ of olive oil alone as controls.

For the comparison of the virilizing activities of androgenic steroids, testosterone and its metabolites including dihydrotestosterone, 5 -androstane- $3 \beta, 17 \beta$ diol, 5-androstane- $3 \alpha, 17 \beta$-diol, androstanedione, androstenedione, androsterone and epiandrosterone were used. The injection of each steroid was made on the 19th day of gestation at three dose levels of
50, 100 and $200 \mu \mathrm{g}$ (1, 2 and $4 \mu l$ of oil solution) except testosterone and dihydrotestosterone which were used at four dose levels of 25, 50, 100 and $200 \mu \mathrm{g}$ $(0.5,1,2$ and $4 \mu l$ oil solution). In a litter, 2 to 3 fetuses were treated with steroid or $4 \mu l$ olive oil alone as controls.

On the 21st day of gestation, the treated and control fetuses were removed from the mother under maternal ether anesthesia and weighed in both experiments. Male fetuses were discarded. Female fetuses were fixed in toto in $10 \%$ neutral formalin solution for 2 weeks. The lower part of the fetal body was routinely embedded in paraffin and sagittal sections were cut at $10 \mu \mathrm{m}$, stained with hematoxylineosin for the measurement of the length of the urovaginal septum according to the method reported previously (Kawashima et al., 1975).

Statistical analysis of the incidence of virilization was made using Student's $t$ test to compare a control group with a group of treated fetuses at each dose (Burn et al., 1950). Analysis of variance for linearity of log-dose response lines as regards the length of the urovaginal septum of fetuses treated with testosterone, dihydrotestosterone and 5 -androstane- $3 \beta, 17 \beta$ diol was made (Burn et al., 1950), Parallel line assay between the regression lines on log-dose response of testosterone and each metabolite preparations was performed by a $3 \times 3$ point design, except the assay between lines of testosterone and 5 -androstane- $3 \alpha$, $17 \beta$-diol in which a $3 \times 2$ point design was used (Emmens, 1948). The relative potency of virilizing activity of each metabolite to that of testosterone was calculated by the method of Burn et al. (1950).

\section{Results}

\section{Critical period for virilizing activity of testosterone}

Fig. 1 shows changes in the length of the urovaginal septum of 21-day-old female fetuses which were treated with $50 \mu \mathrm{g}$ testosterone one to four days earlier. In fetuses treated with testosierone on the 17th day, the length of the urovaginal septum was comparable to that of the oil-treated littermate controls. The length was significantly reduced in those fetuses which were given the hormone on the 18th day, but the most striking abridgment in the urovaginal septum was observed in fetuses treated on the 19th day. In fetuses treated on the 20th day, however, the length of the urovaginal septum was again about the same as in 


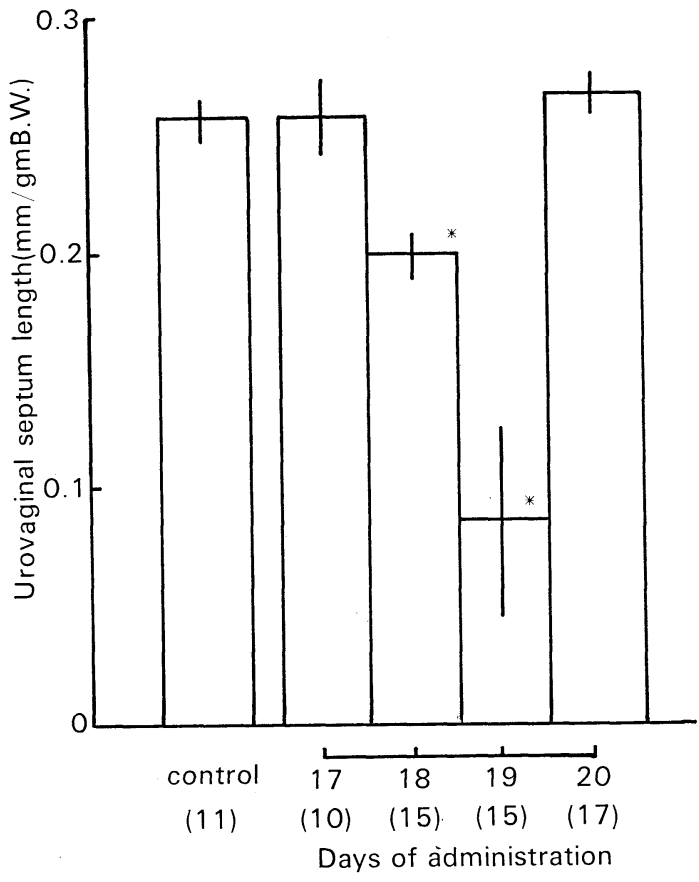

Fig. 1. Critical period of the abridgment of the urovaginal septum after a single injection of testosterone into intrauterine female fetuses. Fifty $\mu \mathrm{g}$ testosterone was injected once on day $17,18,19$ or 20 of gestation, and the fetuses were autopsied on day 21 of gestation. The length of the urovaginal septum is expressed as the length relative to the fetal body weight, and vertical lines represent standard errors. *; The difference from the control value was statistically significant $(\mathrm{p}<0.01)$. The number of fetuse is indicated in parentheses. the controls, suggesting a decreased sensitivity of the urovaginal septum to the hormone.

\section{Virilizing activities of testosterone and its} metabolites

Table 1 shows changes in the length of the urovaginal septum in 21-day-old female fetuses which received various doses of testosterone or its metabolites on the 19th day. Androstenedione, androsterone and epiandrosterone, even at a dose level as high as $200 \mu \mathrm{g}$, did not significantly reduce the length of the urovaginal septum. The most striking abridgment in the urovaginal septum was observed in the fetuses treated with testosterone. Dihydrotestosterone and 5androstane- $3 \beta, 17 \beta$-diol showed somewhat lower virilizing activity than testosterone did. Virilizing activities of 5-androstane$3 \alpha, 17 \beta$-diol and androstanedione were very weak.

The regression line of log-dose response was significantly fitted to linearity within the dose range from 50 to $200 \mu \mathrm{g}$ testosterone as well as dihydrotestosterone and 5 -androstane-3 $\beta, 17 \beta$-diol (Table 2). Both regression lines on log-dose response of testosterone and dihydrotestosterone were demonstrated to be parallel within the dose

Table 1. Changes in the length of the urovaginal septum in 21-day-old female fetuses after a single injection of testosterone and its metabolites on day 19 of gestation, expressed as $\mathrm{mm} / \mathrm{gm}$ body weight with SEM.

\begin{tabular}{|c|c|c|c|c|c|}
\hline \multirow[b]{2}{*}{ Steroids } & \multicolumn{5}{|c|}{ Dose $(\mu \mathrm{g})$} \\
\hline & $\begin{array}{c}\text { Control } \\
\left(\begin{array}{c}\text { treated with } \\
\text { oil alone }\end{array}\right)\end{array}$ & 25 & 50 & 100 & 200 \\
\hline testosterone & $0.25 \pm 0.02(11)$ & $0.21 \pm 0.03$ & $0.12 \pm 0.03 *(13)$ & $0.04 \pm 0.03 * *(14)$ & $-0.01 \pm 0.03 * *(9)$ \\
\hline dihydrotestosterone & $0.26 \pm 0.01$ & $0.24 \pm 0.04(9)$ & $0.14 \pm 0.04 *(11)$ & $0.06 \pm 0.06^{* *}(10)$ & $0.01 \pm 0.04 * *(8)$ \\
\hline $\begin{array}{l}\text { 5-androstane- } 3 \beta \text {, } \\
17 \beta \text {-diol }\end{array}$ & $0.27 \pm 0.01(9)$ & & $0.18 \pm 0.02 *(8)$ & $0.08 \pm 0.04^{* *}(6)$ & $0.03 \pm 0.11^{* *}(6)$ \\
\hline $\begin{array}{l}\text { 5-androstane-3 } \alpha, \\
17 \beta \text {-diol }\end{array}$ & $0.26 \pm 0.02(11)$ & & $0.25 \pm 0.03 \quad(10)$ & $0.16 \pm 0.02^{* *}(5)$ & $0.13 \pm 0.02 * *(6)$ \\
\hline androstanedione & $0.25 \pm 0.03(10)$ & & $0.25 \pm 0.02$ & $0.21 \pm 0.03$ & $0.16 \pm 0.02 *$ \\
\hline androstenedione & $0.26 \pm 0.02(10)$ & & $0.28 \pm 0.02 \quad(11)$ & $0.27 \pm 0.02$ & $0.22 \pm 0.03$ \\
\hline androsterone & $0.26 \pm 0.01$ & & $0.26 \pm 0.02$ & $0.24 \pm 0.03$ & $0.21 \pm 0.05$ \\
\hline epiandrosterone & $0.25 \pm 0.05(6)$ & & $0.22 \pm 0.06(7)$ & $0.24 \pm 0.09$ & $0.21 \pm 0.05$ \\
\hline
\end{tabular}

Numbers of fetuses are indicated in parentheses.

* Significantly different from the control $(\mathrm{p}<0.05)$.

** Significantly different from the control $(\mathrm{p}<0.01)$. 
Table 2. Analysis of variance for linearity of log-dose res:onse lines as regards the length of the urovaginal septum of female fetuses treated with testosterone, dihydrotestosterone and 5 -androstane- $3 \beta, 17 \beta$-diol.

\begin{tabular}{|c|c|c|c|c|c|c|c|c|c|}
\hline \multirow{2}{*}{$\begin{array}{c}\begin{array}{c}\text { Steroids } \\
\text { Dose level }(\mu \mathrm{g})\end{array} \\
\begin{array}{c}\text { Source of } \\
\text { variation }\end{array}\end{array}$} & \multicolumn{3}{|c|}{$\begin{array}{l}\text { testosterone } \\
50,100,200\end{array}$} & \multicolumn{3}{|c|}{$\begin{array}{l}\text { dihydrotestosterone } \\
50,100,200\end{array}$} & \multicolumn{3}{|c|}{$\begin{array}{c}5 \text {-androstane- } 3 \beta, 17 \beta \text {-diol } \\
50,100,200\end{array}$} \\
\hline & $\mathrm{df}$ & $\begin{array}{l}\text { Sum of } \\
\text { squares }\end{array}$ & $\begin{array}{l}\text { Mean } \\
\text { square }\end{array}$ & $\mathrm{df}$ & $\begin{array}{l}\text { Sum of } \\
\text { squares }\end{array}$ & $\begin{array}{c}\text { Mean } \\
\text { square }\end{array}$ & df & $\begin{array}{l}\text { Sum of } \\
\text { squares }\end{array}$ & $\begin{array}{c}\text { Mean } \\
\text { square }\end{array}$ \\
\hline Regression & 1 & 0.093105 & & 1 & 0.089754 & & 1 & 0.071643 & \\
\hline $\begin{array}{l}\text { Deviations from } \\
\text { regression }\end{array}$ & 1 & 0.001833 & $\begin{array}{l}0.001833 \\
\left(\mathrm{~V}_{\mathrm{DR}}\right)\end{array}$ & 1 & 0.001277 & $\begin{array}{l}0.001277 \\
\left(\mathrm{~V}_{\mathrm{DR}}\right)\end{array}$ & 1 & 0.001678 & $\begin{array}{l}0.001678 \\
\left(\mathrm{~V}_{\mathrm{DR}}\right)\end{array}$ \\
\hline Between doses & 2 & 0.094930 & & 2 & 0.091031 & & 2 & 0.073321 & \\
\hline Within doses & 33 & 0.311160 & $\begin{array}{c}0.009429 \\
(\mathrm{Ve})\end{array}$ & 26 & 0.707564 & $\begin{array}{c}0.027214 \\
(\mathrm{Ve})\end{array}$ & 17 & 0.411773 & $\begin{array}{c}0.024221 \\
(\mathrm{Ve})\end{array}$ \\
\hline $\begin{array}{l}\text { Total } \\
\text { Linearity }\end{array}$ & 35 & 0.406100 & & 28 & 0.798613 & & 19 & 0.485095 & \\
\hline $\mathrm{F}$ cal. $\left(\mathrm{V}_{\mathrm{DR}} / \mathrm{Ve}\right)$ & & & 0.194486 & & & 0.046925 & & & 0.069296 \\
\hline $\mathrm{F}_{0.05}$ & & & 4.04 & & & 4.24 & & & 4.45 \\
\hline $\mathrm{df}\left(\mathrm{n}_{1}, \mathrm{n}_{2}\right)$ & & & 1,33 & & & 1,28 & & & 1,17 \\
\hline
\end{tabular}

range from 50 to $200 \mu \mathrm{g}\left(0.082<\mathrm{t}_{0.05}=2.000\right.$, $\mathrm{df}=59)$, and the relative potency of virilizing activity of dihydrotestosterone to that of testosterone was calculated to be 0.810 . Both regression lines on log-dose response of testosterone and 5 -androstane- $3 \beta, 17 \beta$-diol were demonstrated to be parallel within the dose range from 50 to $200 \mu \mathrm{g}\left(0.247<\mathrm{t}_{0.05}=2.008\right.$, $\mathrm{df}=50$ ), and relative potency of the metabolite to testosterone was 0.632 . Also, both dose-response lines within the dose range of 50 to $100 \mu \mathrm{g}$ of testosterone and of 100 to $200 \mu \mathrm{g}$ of 5 -androstane- $3 \alpha, 17 \beta$-diol were parallel $\left(0.675<\mathrm{t}_{0.05}=2.021, \mathrm{df}=42\right)$ and the relative potency of the metabolite to testosterone was calculated to be 0.260 .

\section{Discussion}

Following the injection of testosterone into female fetal rats on day $17,18,19$ or 20 of gestation, microscopic observations at autopsy (day 21) revealed the most striking abridgment in the urovaginal septum in those fetuses which were treated on day 19. It should be noted that the critical time for the fetal virilizing activity of testosterone falls on the 19th day of gestation both in the case of injection into the fetus and in the case of injection into the mother (Kawashima et al., 1977). Among the various testosterone metabolites given on this critical day in the present study, dihydrotestosterone, 5 -androstane- $3 \alpha, 17 \beta$-diol and 5 -androstane- $3 \beta, 17 \beta$-diol were significantly active in virilizing female fetuses, though less active than the precursor compound, testosterone. On the other hand, androstenedione, androsterone ond epiandrosterone were not effective even at a dose as large as $200 \mu \mathrm{g}$.

Schultz and Wilson (1974), in order to test the virilizing activity of several androgens, examined 4-day-old neonatal female rats born to mothers which had been treated subcutaneously with a daily dose of $4 \mathrm{mg}$ androgen on days 14-21 of gestation. These neonatal rats had also been treated with a daily dose of $0.16 \mathrm{mg}$ androgen after birth. According to their results, testosterone caused fetal resorption, so that they failed to see its virilizing effect. However, they noticed a marked virilization in the urogenital tract of the animals treated with dihydrotestosterone and 5-androstane- $3 \alpha, 17$ $\beta$-diol, but did not observe in case of 5 -androstane- $3 \beta, 17 \beta$-diol, androstanedione, androstenedione or androsterone, these observations being relatively well in harmony 
with the present findings. In our results, however, 5 -androstane-3 $\beta, 17 \beta$-diol showed a remarkable virilizing activity in contrast to their negative results.

The sexual differentiation of the male genital tract is principally androgen-dependent (Jost, 1961 and 1970). Also, the female genital tract as well as the urogenital sinus in the fetal stage can be masculinized by androgens secreted from the fetal testis, as was proven in the bovine freemartin phenomenon (Lillie, 1916 and 1917) and in the experiments on implantation of the fetal testis in the rat (MacIntyre et al., 1960; Picon, 1971). Wilson and his coworkers (1971 and 1973) observed in several species, including the rat, that dihydrotestosterone, which is one of the metabolites of testosterone, was a predominant intercellular steroid in the urogenital sinus of fetus, suggesting that dihydrotestosterone was an effective androgen which mediated masculine differentiation of the urogenital sinus. In the present studies, however, testosterone was stronger in virilizing activity than dihydrotestosterone or any other steroid used.

These results suggest that testosterone itself may act directly in the virilization of the fetal target tissues. This is supported by the fact that when incubated with the rat placenta (Sybulski, 1970) or with the fetal rabbit urogenital tubercule (Wilson and Lasnizki, 1971), testosterone was recovered in unchanged form to an extent of more than 50 per cent. However, since the abridgment of the urovaginal septum in female rat fetuses was also induced by testosterone metabolites used in the present study, it is still warranted to consider that testosterone metabolites can also participate, in part, in virilizing the fetal target tissues.

\section{References}

Attal, J. (1969). Endocrinology 85, 280.

Burn, J. H., D. J. Finney and L. G. Goodwin Biological Standardization. Oxford University Press, London (1950).

Dell'acqua, S., S. Mancuso, G. Ericsson and E. Diczfalusy (1966). Biochim. Biophys. Acta 130, 241.

Emmens, C. W. Principales of Biological Assay. Chapman and Hall Ltd., London (1948).

Falconi, D. and G. L. Rossi (1965). Proc. Eur. Soc. Study of Drug Toxicity VI, 150.

Flamigni, C. A., W. P. Collins, E. N. Koullapis and I. F. Sommervillie (1970). Endocrinology 87, 764. Jost, A. (1961). Harvey Lect. 55, 201.

Jost, A. (1970). Phil. Trans. Roy. Soc. Lond. B. 259, 119.

Kawashima, K., S. Nakaura, S. Nagao, S. Tanaka, T. Kuwamura and Y. Omori (1975). Endocrinol. Japon. 22, 439.

Kawashima, K., S. Nakaura, S. Nagao, S. Tanaka, T. Kuwamura and Y. Omori (1977). ibid. 24, 67.

Kobayashi, T., K. Arai, M. Egusa and R. Oh (1969). ibid. 16, 577.

Lillie, F. (1916). Science 43, 611.

Lillie, F. (1917). J. Exp. Zool. 23, 371.

Lipsett, M. B. and W. W. Tullner (1965). Endocrinology 77, 273.

MacIntyre, M. N., J. E. Hunter and A. H. Morgan (1960). Anat. Rec. 138, 137.

Milewich, L. and R. Axelrod (1972). Endocrinology 91, 1101.

Neumann, F. and K. Junkmann (1963). ibid. 73, 33. Neumann, F. and M. Kramer (1964). ibid. 75, 428.

Picon, R. Hormones in Development (edited by Hamburgh, M. and E. J. W. Barrington). Appleton-Century-Crofts Meredith Corporation, New York, p. 645 (1971).

Rampini, E., W. Voigt, B. P. Davis, G. Moretti and S. L. Hsia (1971). Endocrinology 89, 1506.

Rembiesa, R., M. Marchut and A. Warchol (1971). Experientia 27, 1081.

Schltz, F. M. and J. D. Wilson (1974). Endocrinology 94, 979.

Sybulski, S. (1970). Experientia 26, 539.

Wilson, J. D. and I. Lasnitzki (1971). Endocrinology $89,659$.

Wilson, J. D. (1973). ibid. 92, 1192.

Wilson, J. D. and P. K. Siiteri (1973). ibid. 92, 1182. 